\title{
The Quality of Fresh Mackerel Tuna (Euthynnus affinis) Preserved with Different Icing Methods
}

\author{
Sulfiana ${ }^{1}$, Nursinah Amir ${ }^{2}$, Arni Mahmud ${ }^{3}$, Metusalach $^{2 *}$
}

\begin{abstract}
${ }^{1}$ Fisheries Science Study Program, Faculty of Marine and Fisheries Sciences, University of Hasanuddin, Makassar, Indonesia ${ }^{2}$ Department of Fisheries, Faculty of Marine and Fisheries Sciences, University of Hasanuddin, Makassar, Indonesia

${ }^{3}$ Center for Quality Inspection and Implementation of Fishery Products, Government of South Sulawesi, Makassar, Indonesia

*Corresponding author: mminanga@ hotmail.com
\end{abstract}

Received: 15 Nov 2021; Received in revised form: 07 Jan 2022; Accepted: 15 Jan 2022; Available online: 23 Jan 2022

(C)2022 The Author(s). Published by Infogain Publication. This is an open access article under the CC BY license

(https://creativecommons.org/licenses/by/4.0/).

\begin{abstract}
Fish is a highly perishable food material, so the quality is very susceptible to degradation. The damage to the fish may occur starting from catching or harvesting, post-harvest handling to distribution, and consumers. The primary factor causing quality degradation in fish is the activity of enzymes and bacteria, which ultimately shortens the shelf life of the fish. This study aimed to analyze the effect of different icing methods on the quality of mackerel tuna (Euthynnus affinis). This study used a completely randomized factorial design (RAL)involving 2 factor treatments with 3 levels, and each treatment was carried out in 3 replicates. The treatments used were the fish icing method (bulk, 1-layered fish, and 2layered fish)with a ratio of ice and fish 1:1 and a storage durationof 12, 24, and 36 hours. The quality indices analyzed included histamine level, total volatile bases nitrogen (TVB-N), peroxide value, and total plate count (TPC). Results indicated that after $36 \mathrm{~h}$ of storage the histamine, TVB-N, peroxide and TPC contents of the mackerel tuna had increased to $8.1-19.4 \mathrm{mg} / 100 \mathrm{~g}, 47.9 \mathrm{mgN} / 100 \mathrm{~g}, 48.1 \mathrm{mEq} / \mathrm{kg}$, and $1.8 x$ $10^{3}$ colony $/ g$, respectively from the initial values of $8.1 \mathrm{mg} / 100 \mathrm{~g}, 25.7 \mathrm{mgN} / 100 \mathrm{~g}, 5.3 \mathrm{mEq} / \mathrm{kg}$ and $2.6 \times 10^{2}$ colony/g, respectively. Sharp increases were observed in the 1-layered and especially in the 2-layered fish icing methods, while in the bulk icing methods the values of the parameters remained similar to that of the control fish.
\end{abstract}

Keywords-Mackerel tuna, histamine, TVB-N, peroxide value, Total Plate Count.

\section{INTRODUCTION}

Mackerel tuna (Euthynnus affinis) is a commercially important fish with high demand. The protein content of this fish $(21.6-26.3 \%)$ is comparable to that of other species of tuna, but the price is more affordable [1]. Mackerel tuna, like other fish, is easily and quickly damaged (highly perishable), so it is very susceptible to quality degradation. The damage to the fish may occur during fishing, post-catch handling to distribution to consumers [2]. Upon death, the normal defense mechanism of the fish stops and enzymatic, chemical, and bacteriological changes start to take place resulting in the degradation of the fish quality. These changes may be accelerated by unfavorable environmental conditions which handled ultimately shorten the shelf life of the fish. Careless handling and lack of application of cold chain system from the caught time until distributing to consumers cause decrease quality.

Cooling is a preservation process that uses low temperatures to inhibit the enzyme and microbial activity [3]. Using ice is a common and easiest way to handle fishery products [4]. Ice can extend the shelf-life of fish [5].However, the handling of fish carried out by both fishermen and fish traders in Indonesia is still of serious concern because they have not implemented post-catch handling and cold storage systems properly. As a result, 
the fish experienced a significant quality decrease and may pose detrimental impacts to the consumers, both in terms of nutrition and economy. This paper presented data and information on the effect of different icing methods on the quality of mackerel tuna (E. affinis).This paper is expected to contribute some information to support the quality assurance of the mackerel tuna and policies in the field of food security.

\section{MATERIALS AND METHODS}

\subsection{Collection of the Fish Samples}

Samples of mackerel tuna (E. affinis) were obtained from a purse seiner in Bulukumba Regency, South Sulawesi Province, Indonesia. The fish samples were taken immediately after they were lifted onto the purse seiner boat dock, therefore, were still alive by the time they were collected. The fish were transferred into $40 \mathrm{~kg}$ capacity of styrofoam boxes to limit their struggling movements before death, to prevent much earlier and faster deterioration rates.

\subsection{Icing Method Treatments of the Fish Samples}

Immediately upon death, the fish samples were thoroughly washed on board with clean seawater and drained. After draining, the fish were randomly divided into 28 groups according to the experimental treatments ( 3 icing methods and 3 storage times with 3 replicates each and 1 control group). Each group was then transferred into a $10 \mathrm{~kg}$ capacity of styrofoam box and treated according to the experimental icing method treatments. The icing applied were bulking, 1-layered and 2-layered methods with a ratio of fish to ice were 1:1 (w/w). The ice was used machine-grinded block ice having a crystal size of 1-3 $\mathrm{mm}$. The experimental fish were then assigned for a storage time of 12,24 , and $36 \mathrm{~h}$. As for the control group, the fish samples were also iced on board and immediately frozen for $3 \mathrm{~h}$ after landing to maintain the initial quality of the fish. All fish samples were transported to the laboratory less than $4 \mathrm{~h}$ post-landed. In the laboratory, the histamine and total volatile bases nitrogen (TVB-N) contents, peroxide value, and bacterial total plate count (TPC) were analyzed for control fish samples $(0 \mathrm{~h})$, and experimental fish sampled at 12,24 , and $36 \mathrm{~h}$ of storage time.

\subsection{Histamine Analysis [6]}

The histamine content of the fish was determined by the spectrometric method using a spectrofluorometer. As much as $10 \pm 0.1 \mathrm{~g}$ of pre-homogenized fish meat was weighed in a $250 \mathrm{ml}$ beaker glass and then $50 \mathrm{ml}$ of methanol was added. The sample was heated in a water bath for 15 minutes at $60^{\circ} \mathrm{C}$ and cooled at room temperature. The sample was poured into a $100 \mathrm{ml}$ volumetric flask and the volume was adjusted to the mark with methanol. After that, it was filtered using Whatman number 40 filter paper and the filtrate was collected in a sample bottle. The filtrate is then stored in a refrigerator.

A resin column was prepared by inserting glass wool pre-wetted with distilled water into the resin column as high as $1.5 \mathrm{~cm}$. Then, the neutral resin in water medium was poured into the resin column as high as $\pm 8 \mathrm{~cm}$ with the volume of water $1 \mathrm{~cm}$ above the resin. A $50 \mathrm{ml}$ volumetric flask containing $5 \mathrm{ml}$ of $1 \mathrm{~N} \mathrm{HCl}$ was placed under the resin column to collect filtrate passed through the resin.

The collected filtrate was purified by pipetting $1 \mathrm{ml}$ of the into the resin column. The filtrate was allowed to elute and collected in a $50 \mathrm{ml}$ volumetric flask. Distilled water was added when the liquid was about $\pm 1 \mathrm{~cm}$ above the resin and the elution continued. The procedure repeated until the volume of the elutes in the volumetric flask was exactly $50 \mathrm{ml}$. The elute is then stored in the refrigerator. Furthermore, derivatization was carried out in which $50 \mathrm{ml}$ test tubes for each sample were prepared for samples, standards, and blanks. Sample filtrate, working standard solution, and blank $(0.1 \mathrm{~N} \mathrm{HCl})$ were pipetted as much as 5 $\mathrm{ml}$ each into the test tube and $10 \mathrm{ml}$ of $0.1 \mathrm{~N} \mathrm{HCl}$ were added successively and mixed, then $3 \mathrm{ml}$ of $1 \mathrm{~N} \mathrm{NaOH}$ and mixed.After being allowed to stand for 5 minutes, $1 \mathrm{ml}$ OPT $0.1 \%$ was added and mixed and allowed to stand for 4 minutes. Finally, $3 \mathrm{ml} \mathrm{H}_{3} \mathrm{PO}_{4} 3.57 \mathrm{~N}$ were added and mixed. Fluorescence measurement was carried out on samples, standards, and blanks immediately after being prepared with a spectrofluorometer at $350 \mathrm{~nm}$ and $444 \mathrm{~nm}$ of extinction and emission wavelengths, respectively, within 90 minutes.The histamine content was calculated using a standard curve equation as follow:

$$
Y=a+b x
$$

$\mathrm{Y}=$ absorbance

$\mathrm{X}=$ concentration of histamine $(\mathrm{mg} / \mathrm{ml})$

The histamine content was then converted to weight per weight unit using a formula:

$$
\text { Histamine }\left(\frac{m g}{100 g}\right)=A \frac{(\text { final volume }(m l) x f d)}{\text { sample weight }(g)}
$$

$\mathrm{A}=$ Concentration of histamine calculated using the

standard curve $(\mathrm{mg} / \mathrm{ml})$

$\mathrm{fd}=$ Dilution factor 


\subsection{Total Volatile Bases Nitrogen (TVB-N) Analysis [7]}

Analysis of TVB-N was carried out with the stages of extraction, distillation, titration, and calculation of the TVB-N levels. As much as $10 \mathrm{~g} \pm 0.1 \mathrm{~g}$ were weighed a beaker glass, and $90 \mathrm{ml}$ of $6 \%$ perchloric acid (PCA) were added, homogenized with a homogenizer for 2 minutes and filtered with a filter paper. The extract can be stored for a maximum of one week at a temperature of $2-6^{\circ} \mathrm{C}$. At the distillation stage, $50 \mathrm{ml}$ of the extract was put into a distillation tube and a few drops of phenolphthalein indicator were added (colorless solution and in an acidic condition), then a few drops of anti-foaming silicone were added. The distillation tube was then attached to a steam distillation apparatus and $10 \mathrm{ml}$ of $20 \% \mathrm{NaOH}$ were added (at this stage the mixture is red). An Erlenmeyer flaskcontaining $100 \mathrm{ml}$ of $3 \% \mathrm{H}_{3} \mathrm{BO}_{4}$ and 3-5 drops of the prepared Tashiro indicator (purple solution) was also prepared. Steam distillation was carried out for approximately 10 minutes to obtain $100 \mathrm{ml}$ distillate so that the final volume was approximately $200 \mathrm{ml}$ of green solution. A blank was also prepared with the same procedure but the sample was replaced with $50 \mathrm{ml}$ of $6 \%$ PCA. The titration was then performed using a $0.02 \mathrm{~N} \mathrm{HCl}$ solution. The endpoint of the titrationwas indicated by the formation of a purple color in the solution. The Total Volatile Bases Nitrogen (TVB-N) content was calculated as follow:

$$
\begin{aligned}
& \text { TVB }-N(\mathrm{mg} / 100 \mathrm{~g}) \\
& =\frac{(V s-V b) \times N \text { HCl } \times 14,007 \times 2 \times 100}{\text { sample weight }(g)}
\end{aligned}
$$

Vs = volume of $\mathrm{HCl}$ used to titrate sample $(\mathrm{ml})$

$\mathrm{Vb}=$ volume of $\mathrm{HCl}$ used to titrate blank $(\mathrm{ml})$

$\mathrm{N} \quad=$ normality of $\mathrm{HCl}$ solution

$14,007=$ atomic weight of nitrogen

$2=$ dilution factor

\subsection{Peroxide Value Analysis [8]}

The peroxide value was analyzed by the AOCS Cd8b-90 method, whichwas to determine the peroxide number using the principle of titration of iodine released from potassium iodide compounds by peroxide using standard thiosulfate solution as the titrant and starch solution as an indicator. This method detects all substances that oxidize potassium iodide under acidic conditions. An approximately $5 \mathrm{~g}$ of sample were weighed and put in a $250 \mathrm{ml}$ Erlenmeyer flask, added with $30 \mathrm{ml}$ mixture of acetic acid and chloroform in a ratio of 3:2, then added with $0.5 \mathrm{ml}$ of potassium iodide (KI) solution.The mixture solution was then shaken carefully then added with $30 \mathrm{ml}$ of distilled water. The solutionthen titrated with $0.01 \mathrm{~N}$ sodium thiosulfate $\left(\mathrm{Na}_{2} \mathrm{~S}_{2} \mathrm{O}_{3}\right)$ to a yellow color, and $0.5 \mathrm{ml}$ of $1 \%$ starch solutionwas added which changed the color of the solution to blue. The titrationwas continued was continued until the blue color of the solution disappeared.

The peroxide value was calculatedusing the following equation:

$$
\text { Peroxide value }=\frac{S \times M \times 1000}{\text { sample weight }(g)}
$$

$\mathrm{S}$ = volume of sodium thiosulfate used to titrate sample (ml)

$\mathrm{M}=$ concentration of sodium thiosulfate $(0.01 \mathrm{~N})$

\subsection{Total Plate Count (TPC) Analysis [9]}

Sample of as much as $25 \mathrm{~g}$ was weighed aseptically and added with $225 \mathrm{ml}$ of Butterfield's phosphate-buffered solution, then homogenized for 2 minutes. This homogenatewas a $10^{-1}$ dilution solution. Using a sterile pipette, $1 \mathrm{ml}$ of the homogenate was taken and put into a bottle containing $9 \mathrm{ml}$ of Butterfield's phosphate-buffered solution so that a sample with a dilution of $10^{-2}$ was obtained. At each dilution, shaking was carried out at least 25 times, then the same was done for the $10^{-3}, 10^{-4}, 10^{-5}$, and so on according to the sample conditions. Furthermore, $1 \mathrm{ml}$ of each dilution was put into a sterile petri dish in duplicate using a sterile pipette. Into eachpetri dish containing the sample, 12-15 $\mathrm{ml}$ of Plate Count Agar (PCA) media which has been cooled to $45^{\circ} \mathrm{C}$ were added. After the agar solidified, the petri dish was put into an incubator in an inverted position for 48 hours at $35^{\circ} \mathrm{C}$. After incubation the number of bacterial colonies in the petri dish was counted using a colony counter. Only the petri dishescontaining the bacterial colonies between 25250 colonies were used in the calculation of the total plate count (TPC).

The TPCwas calculated with the following equation:

$$
T P C=\frac{\sum \mathrm{C}}{\left[\left(1 \mathrm{x} \mathrm{n}_{1}\right)-\left(0,1 \mathrm{x} \mathrm{n}_{2}\right)\right] \times(\mathrm{d})}
$$

$\mathrm{TPC}=$ Total plate count, expressed in colony per $\mathrm{g}$

$\Sigma \mathrm{C}=$ Number of colony in all plates counted

$\mathrm{n} 1=$ Number of plates in the first dilution calculated

$\mathrm{n} 2=$ Number of plates in the second dilution calculated

$\mathrm{d}=$ First dilution

\subsection{Data Analysis}

The data obtained were analyzed using analysis of variance (ANOVA), and since ANOVA indicated the presence of significant differences, a Tuckey test was employed to identify treatments having significant differences. For statistical analysis, SPSS version 16.0 package was used. Significant differences were determined at $95 \%$ confidence level $(\alpha=0.05)$. 


\section{RESULT AND DISCUSSION}

The histamine, total volatile bases nitrogen (TVB-N), peroxide value, and total plate count (TPC) contents of the mackerel tuna (E. affinis) samples preserved with different icing methods were presented in Table 1.

Table 1. The histamine, TVB-N, peroxide value, and total plate count of the experimental mackerel tuna (E. affinis).

\begin{tabular}{lccccc}
\hline \multicolumn{1}{c}{ Icing Method } & $\begin{array}{c}\text { Storage } \\
\text { Time }(\mathbf{h})\end{array}$ & $\begin{array}{c}\text { Histamine } \\
(\mathbf{m g} / \mathbf{1 0 0 g})\end{array}$ & $\begin{array}{c}\text { TVB-N (mgN/100 } \\
\text { g) }\end{array}$ & $\begin{array}{c}\text { Peroxide Value } \\
(\mathbf{m E q} / \mathbf{k g})\end{array}$ & $\begin{array}{c}\text { Total Plate Count } \\
(\mathbf{c o l o n y} / \mathbf{g})\end{array}$ \\
\hline Control & 0 & $8.1 \pm 0.06^{\mathrm{e}}$ & $25.7 \pm 0.19^{\mathrm{f}}$ & $5.3 \pm 0,07^{\mathrm{h}}$ & $2.6 \times 10^{2} \pm 19.00^{\mathrm{f}}$ \\
Bulk Method & 12 & $8.5 \pm 0.17^{\mathrm{e}}$ & $28.7 \pm 0.36^{\mathrm{d}}$ & $8.0 \pm 0.02^{\mathrm{g}}$ & $3.2 \times 10^{2} \pm 11.55^{\mathrm{f}}$ \\
& 24 & $8.5 \pm 0.10^{\mathrm{e}}$ & $27.7 \pm 0.37^{\mathrm{e}}$ & $25.9 \pm 0.35^{\mathrm{e}}$ & $8.3 \times 10^{2} \pm 15.28^{\mathrm{e}}$ \\
& 36 & $8.6 \pm 0.09^{\mathrm{e}}$ & $29.1 \pm 0.03^{\mathrm{d}}$ & $35.8 \pm 0.54^{\mathrm{b}}$ & $1.2 \times 10^{3} \times 115.47^{\mathrm{c}}$ \\
1-Layered Method & 12 & $14.1 \pm 0.06^{\mathrm{cd}}$ & $38.4 \pm 0.06^{\mathrm{c}}$ & $7.2 \pm 0.55^{\mathrm{g}}$ & $1.0 \times 10^{3} \times 57.74^{\mathrm{d}}$ \\
& 24 & $13.7 \pm 0.24^{\mathrm{d}}$ & $38.6 \pm 0.39^{\mathrm{c}}$ & $20.6 \pm 0.77^{\mathrm{f}}$ & $1.2 \times 10^{3} \times 57.74^{\mathrm{c}}$ \\
2-Layered Method & 36 & $14.2 \pm 0.10^{\mathrm{c}}$ & $39.1 \pm 0.06^{\mathrm{c}}$ & $27.7 \pm 0.60^{\mathrm{d}}$ & $1.5 \times 10^{3} \times 100^{\mathrm{b}}$ \\
& 12 & $18.5 \pm 0.21^{\mathrm{b}}$ & $47.2 \pm 0.05^{\mathrm{b}}$ & $8.4 \pm 0.34^{\mathrm{g}}$ & $1.3 \times 10^{3} \times 57.74^{\mathrm{bc}}$ \\
& 24 & $19.2 \pm 0.35^{\mathrm{a}}$ & $47.9 \pm 0.30^{\mathrm{a}}$ & $30.0 \pm 0.94^{\mathrm{c}}$ & $1.4 \times 10^{3} \times 57.74^{\mathrm{b}}$ \\
& 36 & $19.4 \pm 0.09^{\mathrm{a}}$ & $46.5 \pm 0.09^{\mathrm{b}}$ & $48.1 \pm 0.30^{\mathrm{a}}$ & $1.8 \times 10^{3} \times 57.74^{\mathrm{a}}$
\end{tabular}

Values are means \pm standard deviations. Different superscripts for the same column indicated significant differences.

\subsection{Histamine Content}

The histamine content of the experimental fish ranged from 8.1-19.4 mg/100 g meat. During the study, fish in the bulk icing method had their histamine increased slightly. Meanwhile the fish in the 1-layered and especially 2layered icing methods exhibited a much greater increase in their histamine as compared to the initial histamine content.

The result of ANOVA) showed that the histamine level of mackerel tuna (E. affinis) was affected $(\mathrm{p}<0.05)$ by the icing method and storage time. Tukey's test showed that the histamine of the control fish and the fish in the bulk icing method was similar $(p>0.05)$, but both was significantly $(p<0.05)$ different from that of the fish 1 and2-layered icing methods. Fish in the 1- and 2-layered icing methods also showeda significant $(\mathrm{p}<0.05)$ difference in their histamine contents. For the storage time, Table 1 also showed that there were small, although some significant $(\mathrm{p}<0.05)$, increases in the histamine contents of the mackerel tuna with the increase in the storage duration. Therefore, the greatest effect was impacted upon by the icing methods. The low and relatively unchanged histamine of the fish in the bulk icing method was due tofact that every single fish was completely covered by the ice, resulting in a quicker decrease in the fish temperature and a slow formation of the histamine. High temperature is one of the primary contributors to a rapid formation of histamine.
Layering fish does not permit the whole body surface to be in a direct contact with ice causing anun-homogenous cooling effect of the ice and a slow decrease in the fish body temperature. The more or ticker the fish layer the greater body part doesnot exposed to ice and the slower the cooling rate, which permits some part of the fish body to be at higher temperature for a longer period of time. Longer period at high temperature facilitates more enzymatic decarboxylation of amino acid histidine, resulting in higher histamine level. Thus, a complete covering of fish body with ice proves to be effective in minimizing the formation of histamine as shown by the fish in the bulk icing method.

Histamine is used as an indicator of food quality and safety because high histamine content causes toxic effect in humans [10]. The results showed that the histamine level of mackerel tuna before treatment were $8.1 \mathrm{mg} / 100 \mathrm{~g}$ of meat. After being treated with different icing methods for 36 hours, the histamine level increased to a maximum of $19.4 \mathrm{mg} / 100 \mathrm{~g}$ meat. The histamine content in mackerel tuna during the study were still categorized as safe and could be used as raw material for food products. The FDA standard for histamine content is maximum $50 \mathrm{mg} / 100 \mathrm{~g}$.

Icing lowers the fish body temperature which retards the formation of histamine. Most histamine-forming bacteria are not able to perform metabolism perfectly at low temperatures [11], although some bacteria are still able to carry out the minimum activity at low temperatures 
[12]. Several bacteria such as Morganella morganii, Klebsiella oxytoca, Staphylococcus hominis, and Enterococcus were reported to be active in producing histamine in tuna loin stored at low temperatures [13]. The effectiveness of low temperature using permafrost in controlling histamine production has also been demonstrated by [14]in mackerel. Histamine production will rapidly increase if fish is stored at temperatures of $21.1^{\circ} \mathrm{C}$ or more [15]. The study of [16] demonstrated that the growth of histamine-forming bacteria in tuna is very rapid at a temperature of $30^{\circ} \mathrm{C}$ within 24 hours of storage, with histamine content reaching $56.62 \mathrm{mg} / 100 \mathrm{~g}$ and 78.76 $\mathrm{mg} / 100 \mathrm{~g}$. Histamine is formed by decarboxylation of the amino acid histidine by the exogenous decarboxylase enzyme produced by microbes [17]. The rapid increase in histamine level is the result of the optimum growth of histamine-producing bacteria, the action of the histidine decarboxylase enzyme, and the availability of substrate for the histidine decarboxylase enzyme [18].

\subsection{Total Volatile Bases Nitrogen (TVB-N)Content}

The TVB-N content of the experimental mackerel tuna ranged from 25.7 - $47.9 \mathrm{mgN} / 100 \mathrm{~g}$ of meat (Table 1). The bulk icing methods permitted a small increase in the TVB-N, however much greater increases took place in the fish of the 1 and 2-layered icing methods. Table 1 also showed that the TVB-N of the fishwas relatively stable throughout the storage time.The results of ANOVA showed that the TVB-N contentof themackerel tuna was significantly $(\mathrm{p}<0.05)$ affected by the icing methods and the storage time, and that there was a significant interaction effect between the icing methods and the storage time on the TVB-N content of the fish. The Tukey test demonstrated that the TVB-N contents of the fish were significantly $(p<0.05)$ different between the treatments, being highest in the fish 2-layered followed by 1-layered and bulk icing methods. Although only a slight increase in the TVB-N of the fish took place in the bulk icing method, this increase was significant as compared to the initial TVB-N content in the control fish.

TVB-N is the product of protein decomposition caused primarily by bacterial enzymes, therefore the quality deterioration of fresh fish can be determined through the content of the TVB-N. The TVB-N levels are influenced by the number of bacteria surviving the preservation treatment given. In the present study, the number of surviving bacteria might have been different between the icing methods applied, so that the product of bacterial metabolism in the form of TVB-N were also different between the treatments.
In this study, only the bulk icing method was capable of rendering the TVB-N content within the standard (max. $30 \mathrm{mgN} / 100 \mathrm{~g}$ meat) for at least 36 hours of storage. According to [19], fish is considered to be very fresh if the TVB-N contentis less than $10 \mathrm{mgN} / 100 \mathrm{~g}$.Fish with TVB$\mathrm{N}$ between $10-20 \mathrm{mgN} / 100 \mathrm{~g}$ is considered as fresh and between $20-30 \mathrm{mgN} / 100 \mathrm{~g}$ is not fresh but still acceptable for consumption. Fish containing the TVB-N of more than $30 \mathrm{mgN} / 100 \mathrm{~g}$ is classified as rotten fish. According to [20] the longer the storage timethe higher the TVB-N leveldue to the protein degradation and microbial spoilage. A large number of microbes in fish causesthe protein degradation process into basic nitrogen compounds faster so that the concentration of TVB-N also increases sharply [21]. The difference in TVB-N levels in each treatment is thought to be caused by the difference in the number of bacteria growing in each treatment, thus the amount of metabolic product in the form of TVB-N is also different.According to [22], the increase in TVB-N is caused by an increase in the number of bacteria in connection with the continuing process of quality deterioration. TheTVB-N content also varies by species, age, sex, and harvest time of thefish [23]. TheTVB-N is also affected by the amount of nonprotein nitrogen present in fish, all of which depend on the type of food, fishing season, and fish size [24].

\subsection{Peroxide Value}

The peroxide value of the experimental mackerel tuna was between 8 and $48.1 \mathrm{mEq} / \mathrm{kg}$ meat, while in the control fish was $5.3 \mathrm{mEq} / \mathrm{kg}$. The results of ANOVA indicated that there was an interaction and significant effect $(p<0.05)$ of the icing method and storage time on the peroxide valueof the fish. Tukey test showed that differences existed in the peroxide values of the fish between icing methods as well as within icing method between the storage time.

The peroxide value is a measure of the degree of fat breakdown. Unsaturated fatty acids can bind oxygen to form peroxides [25]. The higher the peroxide value, the higher the fat damage, and the lower the peroxide value, the better the quality of the oil. According to[26], good quality of oil has a low peroxide value. The high peroxide value in fresh mackerel tuna may indicate the high conent of unsaturated fatty acids. Unsaturated, and especially polyunsaturated fatty acids, are highly susceptible to oxidation. High content of unsaturated fats, presence of oxygen and metals as well as high temperature are the primary factors in the damage of fats, and hence, the higher the peroxide value. [27]Stated that the increase in the peroxide value is caused by the breaking of the double bonds due to the heating temperature. Higher fat contents provide a greater opportunity for auto-oxidation to take 
place which will eventually lead to higher peroxide values [28]. Fat oxidation reactions increase in more acidic conditions. Acidic condition is caused by microbial activity that produces acid, such aslactic acid bacteria [29]. High temperature has also been demonstrated to cause an increase in the peroxide content of the fish $[30 ; 31]$.

\subsection{Total Plate Count (TPC)}

The total plate count of the mackerel tuna experimental fish was essentially low, between $2.6 \times 10^{2}$ col./g for the control fish and $1.8 \times 10^{3} \mathrm{col} . / \mathrm{g}$ of meat after stored for 36 hours. The results of ANOVAindicated that the icing method applied and storage time used exerted a significant $(p<0.05)$ effect on the TPC of the fish. Tukey test showed that the TPC of the 12 hours-stored bulk-iced fish was similar $(p>0.05)$ to that of the control fish, but both were lower $(p<0.05)$ than those of the rest of the treatments which also showed variation between them. The TPC was significantly $(\mathrm{p}<0.05)$ increased with storage time regardless of the icing methods. Similarly, the TPC of the fish from each icing method differed significantly $(\mathrm{p}<0.05)$ with an order of the bulk <1-layered <2-layered icing methods. Nevertheless, themuch lower TPC values in the experimental fish as compared the standard of max. $5 \mathrm{x}$ $10^{5} \mathrm{col} . / \mathrm{g}$ of meat [32] indicated the effectiveness of the icing methods applied in inhibiting the growth of bacteria. Thus, the mackerel tuna preserved for 36 hours with different icing methods in this study was bacteriologically of good quality. The increase in the TPC is usually due to the high temperature and the abundant availability of nutrients in the fish as substrates for the bacterial growth. Fish meat is an excellent substrate for bacteria because it provides compounds such as nitrogen, carbon, and other nutrients for their needs [33]. Upon death, the entire order of enzymes regulating the fish's life cycle falls apart. Digestive enzymes that previously digestfood in the fish intestine eventually decompose the fish body and tissues [34]. According to [35],bacteria is the dominant microorganism in the deterioration process of the fish. Furthermore, [36] stated that several factors affecting the freshness of fish include microbial contamination physical defect and injury due to the-catching process, long selling time, poor sanitation, exposure to room temperature over a long period, and various other factors.

\section{CONCLUSION}

Different icing methods in this study exerted different effects on the quality of the mackerel tuna (E. affinis). The best icing method was the bulk method as it permitted the ice to completely covering the whole body of fish, causing a more homogenous and faster decrease in fish body temperature, thus suppressing the deterioration processes and resulting a better quality of the fish as compared to the layering fish icing methods.

\section{REFERENCES}

[1] M. S. Milo, L. M. Ekawati, dan F. S. Pranata. Mutu Ikan Tongkol (Euthynnus affinis) di Kabupaten Gunungkidul dan Sleman Daerah Istimewa Yogyakarta," Fakultas Teknobiologi Universitas Atma Jaya Yogyakarta”,, 2011. In Indonesian.

[2] N. Nuraisyah, A. F. P. Nelwan, dan S. A. Farhun. Produktivitas penangkapan ikan tongkol (Euthynnus affinis) menggunakan purse seine di perairan Bontobahari kabupaten Bulukumba dan hubungan dengan kondisi oseanografi." Jurnal IPTEKS PSP. Vol 6 (12)"., 2019. In Indonesian.

[3] N. N. Afiyah, S. Iin, dan L. Ernani. Pengaruh rantai distribusi dan kualitas ikan tongkol (Euthynnus sp.) dari PPP Blanakan selama pendistribusian ke daerah konsumen." Jurnal Sosek Kp Vol. 14 No 2. Hal 225-237'., 2019. In Indonesian.

[4] A. I. Pratiwi, A. Husni, S. A. Budhiyantim, dan B. R. Aji. Karakteristik mutu wader pari hasil budidaya pada berbagai suhu penyimpanan." Jurnal Pengolahan Hasil Perikanan Indonesia, 20 (1), 123-130”, 2017. In Indonesian.

[5] T. A. Nugroho, Kiryanto, dan B. A. Aditya. Kajian eksperimen penggunaan media pendingin ikan berupa es basah dan ice pack sebagai upaya peningkatan performance tempat penyimpanan ikan hasil tangkapan nelayan. "Jurnal Teknik Perkapalan. Vol. 4 (4)”., 2016. In Indonesian.

[6] [BSN] Badan Standar Nasional. Cara Uji Kimia Bagian 10. Penentuan Kadar Histamin dengan Spektroflometri dan Kromatografi Cair Kinerja Tinggi (KCKT) Pada Produk Perikanan. Jakarta: Badan Standarisasi Nasional., 2016. In Indonesia.

[7] [BSN] Badan Standarisasi Nasional. Cara Uji Kimia Bagian 8. Penentuan Kadar Total Volatil Base Nitrogen (TVB-N) dan Trimetil Amin Nitrogen (TMA-N) Pada Produk Perikanan. Jakarta: Badan Standarisasi Nasional., 2009. In Indonesia.

[8] AOCS American Oil Chemists Society. Official Methods and Recommended Practices of The AOCS. Ed-4. Champaign, Illinois: AOCS Press., 1998.

[9] [BSN] Badan Standarisasi Nasional. Cara uji mikrobiologi Bagian 3. Penentuan Angka Lempeng Total (ALT) pada produk perikanan. Jakarta: Badan Standarisasi Nasional., 2015. In Indonesia.

[10] J. Oehlenschlager. Introduction - importance of analysis in seafood and seafood products, variability and basic concepts. In: In: Handbook of Seafood and Seafood Product analysis. "Journal of Fisheries Sciences". B

[11] S. I. M. Wodi, W. Trilaksani, M. Nurmila. Histamin dan identifikasi bakteri pembentuk histamin pada tuna mata 
besar (Thunnus obesus). "Jurnal Teknologi Perikanan dan Kelautan Vol. 9 No. 2 Hal. 185-192”., 2018. In Indonesian.

[12] I. G. S. Pandit. Penerapan teknik penanganan yang berbeda terhadap kualitas ikan segar sebagai bahan baku pembuatan ikan pindang. "Jurnal Perikanan Universitas Gadjah Mada 19 (2):89-96 ISSN: 0853-6384 elISSN:2502-5066”., 2017. In Indoensian.

[13] M. V. Silva, O. Ferreiria, I. Plestilova, L. Gibbs, and P. A. 2002. Production of histamine and tyramine by bacteria isolated from Portuguese vacuum-packed cold-smoked fish. "Food Control 13:457-461"., 2002.

[14] T. Chamberlain. Histamine levels in long lined tuna in Fiji : A comparison of samples from two different body sites and the effect of storage at different temperatures. "J.Nat.Sci. 19 : 30-34"., 2001.

[15] H. Oucif, M. S. Abi, S. E. Ayad. Lipid oxidation and histamine production in Atlantic mackerel (Scomber scomborus) versus time and mode of conversation. "Journal of Life Sciences. 6: 713-720”., 2012.

[16] [FDA] Food and Drug Administration. Scombrotoxin (Histamine) Formation. In: Fish and Fishery Product Hazard and Control Guide. Washington: Department of Health and Human Service, Center for Food Safety and Applied Nutrition., 2011.

[17] S. B. Patange, M. K. Mukundan, and K. A. Kumar. A simple and rapid method for colorimetric determination of histamine in fish fresh. "Food Control 16: 465-472”, 2005.

[18] A. Ndaw, A. Zinedine, and A. Bouseta. Assessment of histamine formation during fermentation of sardine (Sardina pilchardus) with lactic acid bacteria. "World Journal of Dairy and Food Science 2(2): 42-48”., 2007.

[19] M. Kanki, T. Yoda, T. Tsukamoto, and E. Baba. Histidine decarboxylase and its role in the accumulation of histamine in tuna and dried saury. "Applied and Environmental Microbiology 72(5): 1467-1473”., 2007.

[20] I. Nurjanah, Setyaningsih, Sukarno, dan M. Muldani.Kemunduran mutu ikan nila merah (Oreochromis sp.). “Jurnal Teknologi Hasil Perikanan Indonesia. Vol XI Nomor 2",., 2004. In Indonesian.

[21] F. Ariyani, Yulianti. Dan T. Martati. Studi perubahan kadar histamin pada pindang tongkol (Euthynnus affinis) selama penyimpanan. "Jurnal Penelitian Perikanan Indonesia 10 (3) : 35-46”., 2004. In Indonesian.

[22] L. L. Barodah, Sumardianto, E. Susanto.Efektivitas serbuk Sargassum polycystum sebagai antibakteri pada ikan lele (Clarias sp.) selama penyimpanan dingin. "Jurnal Pengetahuan \& Bioteknologi Hasil perikanan. Vol. 6 No. 1. ISSN : 2442-4145”,, 2017. In Indonesian.

[23] Ibrahim, R. Nurcahaya, D.E. 2008. Pendinginan ikan Bandeng (Chanos chanos forsk) dengan es air laut serpihan (Sea water flake Ice) dan analisis mutunya. Universitas Diponerogo. “Jurnal Saintek Perikanan, 3 (2) : 27-32”., 2008. In Indonesian.

[24] B. Kilinc, and S. Cakli. The determination of the shelf-life of pasteurized and nonpasteurized sardine (Sardina pilchards) marinades stored at $40^{\circ} \mathrm{C}$. "International Journal Food Science Technology 40:265-271 ”., 2005.

[25] A. E. Goulas, and M. G. Kontominas. The combined effect of light salting, modified atmosphere packaging, and oregano essential oil on the shelf-life of sea bream (Sparus aurata): biochemical and sensory attributes. "Food Chemistry 100: 287-296”., 2007.

[26] G. R. Ginanjar, I. T. Maulana, danR.A. Coder. Ekstraksi minyak dari kijing (Pilsbryoconcha exilis lea) serta analisis kandungan asam lemak menggunakan $\mathrm{Kg}$-Sm. “[Prosiding], 79-85”., 2015. In Indonesian.

[27] A. Panagan, Y. Heni, dan U. G. Jojor.Analisis kualitas dan kuantitatif asam lemak tak jenuh omega-3 dari minyak ikan patin (Pangasius pangasius) dengan metoda kromatografi gas. "Jurnal Penelitian Sains. Volume 14. Nomer 4 (C) 14409”., 2011. In Indonesian.

[28] Z. Edwar,S. Heldrian,Y. Ety, and S. Delmi. Effect of heating on fatty acid saturation of palm cooking oil and corn cooking oil. "Journal of the Indonesian Medical Association. Volumes 61”., 2011.

[29] Fahrul, dan Metusalach. Kualitas ikan segar yang dijual eceran keliling di kota makassar. "Fakultas Ilmu Kelautan dan Perikanan. Universitas Hasanuddin. Makassar”., 2014. In Indonesian.

[30] R. Karas, M. Skvarca, and B. Zlender. Sensory quality of standard and light mayonnaise during storage. "Food Teknol. Biotechnol. 40 (2) 119-127”,., 2002.

[31] V. W. Monintja, F. Fatimah, and V.S. Kamu. Nilai peroksida dari bakasang ikan tuna (Thunnus sp.) pada beberapa kondisi pengolahan. "Journal Plant Farmasi. Vol 7 No 2. ISSN 2302-2493”., 2018

[32] R. Husain, E. Supramono, Harmayani. C. Hidayat.Kinetik oksidasi ikan tuna (Thunnus sp.) selama penyimpanan. “Agritech. 36(2):176-181”., 2016. In Indonesian.

[33] J. Rahmi.Kualitas Ikan Cakalang(Katsuwonus pelamis) Segar Pasca Pendaratan di PPI Lappa Sinjai Sampai Pemasaran Akhir di Kabupaten Sinjai. Skripsi. "University Hasanuddin. Makassar".,2018.In Indonesian.

[34] [BSN] Badan Standarisasi Nasional. Ikan Segar, SNI 2729.2013. Jakarta: Badan Standarisasi Nasional. 2013. In Indonesian.

[35] Y. R. Hidayah, Winarni, dan B.E. Susatyo.Pengaruh penggunaan lengkuas terhadap sifat organoleptik dan daya simpan ikan nila segar. "Jurnal Jurusan Kimia FMIPA Universitas Negeri Semarang”., 2015. In Indonesian.

[36] S. I .M. Wodi, F. J. Rieuwpassa, dan E. Cahyono.Peningkatan kualitas hasil tangkapan melalui penerapan sistem rantai dingin di kelurahan Santiago. “Jurnal Ilmiah Tategkorang. 2(2) : 70-72”., 2018. In Indonesian. 